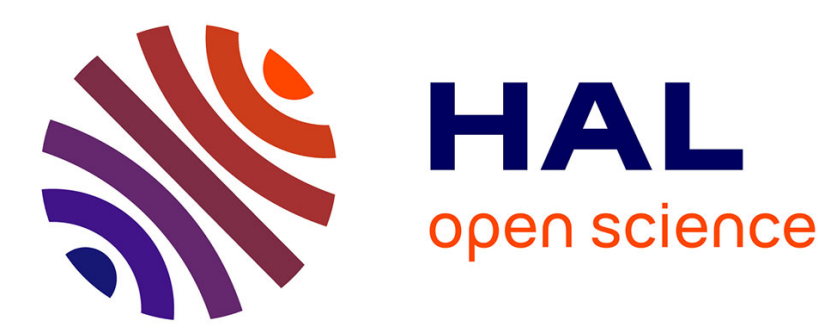

\title{
Fallen in a dead ear: intralabyrinthine preservation of stapes in fossil artiodactyls
}

\author{
Maeva Orliac, Guillaume Billet
}

\section{To cite this version:}

Maeva Orliac, Guillaume Billet. Fallen in a dead ear: intralabyrinthine preservation of stapes in fossil artiodactyls. Palaeovertebrata, 2016, 40 (1), 10.18563/pv.40.1.e3 . hal-01897786

\section{HAL Id: hal-01897786 \\ https://hal.science/hal-01897786}

Submitted on 17 Oct 2018

HAL is a multi-disciplinary open access archive for the deposit and dissemination of scientific research documents, whether they are published or not. The documents may come from teaching and research institutions in France or abroad, or from public or private research centers.
L'archive ouverte pluridisciplinaire HAL, est destinée au dépôt et à la diffusion de documents scientifiques de niveau recherche, publiés ou non, émanant des établissements d'enseignement et de recherche français ou étrangers, des laboratoires publics ou privés. 
See discussions, stats, and author profiles for this publication at: https://www.researchgate.net/publication/297725060

\section{Fallen in a dead ear: intralabyrinthine preservation of stapes in fossil artiodactyls}

Article $\cdot$ March 2016

DOI: $10.18563 /$ pv.40.1.e3

CITATIONS

2 authors:

Maeva Orliac

Université de Montpellier

76 PUBLICATIONS 745 CITATIONS

SEE PROFILE
READS

254

Some of the authors of this publication are also working on these related projects:

The ear region of Artiodactyla View project

Origin, evolution, and dynamics of Amazonian-Andean ecosystems View project

Guillaume Billet

Muséum National d'Histoire Naturelle

103 PUBLICATIONS 862 CITATIONS

SEE PROFILE 


\title{
Fallen in a dead ear: intralabyrinthine preservation of stapes in fossil artiodactyls
}

\author{
Maeva J. ORLiAC ${ }^{\mathrm{a}}$, Guillaume BILLET ${ }^{\mathrm{b}}$ \\ anstitut des Sciences de l'Evolution, UMR 5554 CNRS, IRD, EPHE, Université de Montpellier, Place Eugène Bataillon, 34095 \\ Montpellier cedex 5, France \\ ${ }^{b}$ CR2P - Sorbonne Universités, UMR 7207 CNRS, MNHN, Univ Paris 06 - Muséum national d'Histoire naturelle, 8 rue Buffon, \\ CP 38, 75005 Paris, France \\ * Corresponding author: maeva.orliac@univ-montp2.fr
}

\begin{abstract}
The stapes is the last of the middle ear ossicle chain and the smallest bone of the mammalian skeleton. Because it rests on the membrane of the fenestra vestibuli during life, the stapes may often fall within the bony labyrinth cavity when soft structures decay after death. In this work, we highlight the unexpected role that the bony labyrinth plays in the preservation of the stapes. Systematic investigation of the bony labyrinth of 50 petrosal bones of extinct and extant artiodactyls led to the discovery of eight cases of "intralabyrinthine" stapes. Three dimensional reconstructions of these stapes allow documenting stapes morphology of four extinct artiodactyl taxa: Microstonyx erymanthius (Suidae), Elomeryx borbonicus (Hippopotamoidea), ?Helohyus plicodon (Helohyidae), and an undetermined Cainotheriidae; and four extant ones Choeropsis and Hippopotamus (Hippopotamidae), and Tayassu and Phacochoerus (Suoidea). ?Helohyus plicodon from the Middle Eocene documents the oldest stapes known for the order Artiodactyla. Morphological study and metric analyses of our sample of artiodactylan stapes show that stapes are likely to carry relevant phylogenetic characters/signal within artiodactyls, and a potential Euungulata signature.
\end{abstract}

Keywords: inner ear, bony labyrinth, allometry, middle ear ossicles

Submitted 9 September 2015, Accepted 27 January 2016

Published Online 9 March 2016, doi: 10.18563/pv.40.1.e3

(C) Copyright Maeva Orliac March 2016

\section{INTRODUCTION}

The middle ear ossicles, the malleus, the incus, and the stapes, are contained within the middle ear space. They play a crucial role in sound transmission to the inner ear of mammals by performing an anatomical impedance match that permits sound waves from the air (and the tympanic membrane) to enter the fluid-filled labyrinth (cochlea). The stapes is the most internal of the middle ear ossicle chain and contacts the membrane of the fenestra vestibuli. These ossicles are the smallest bones of the skeleton of modern mammals; their small size in adult therians is due to a large negative ontogenetic allometry (Luo, 2011). Their size and fragility in therians explain why few middle ear ossicles are found in the fossil record. However, some stapes - the smallest of ear ossicles (Nummela, 1995) have been described from taxa known from the Mesozoic Period for fossil Mammaliaformes (e.g., few fragmentary stapes from Morganucodon and Haldanodon (Kermack et al., 1981; Ruf et al., 2013)). Several multituberculate stapes have been documented from Palaeocene deposits (e.g., Meng, 1992; Miao \& Lillegraven, 1986; Lillegraven \& Krusat, 1991; Allin \& Hopson, 1992; Crompton \& Luo, 1993), and Eutherian stapes have been found in the Late Cretaceous (Archibald, 1979). Given the interest for the first steps of inner ear bones evolution, stapes have been intensively searched for in basal therian groups. On the other hand, relatively few fossil stapes are documented for the crown clade Placentalia. To our knowledge, these include some primates (e.g., the Eocene genera Notharctus and Djebelemur (Gregory, 1920; Benoit et al., 2013); Pliocene Homininae (Moggi-Cecchi \& Collard, 2002)), the Eocene palaenodont Metacheiromys (Patterson et al., 1992), a variety of fossil sloths and cingulates (e.g.,
Woodward, 1900; Guth, 1957, 1961; Patterson et al., 1992, Blanco \& Rinderknecht, 2012), basilosauroids (e.g., Lancaster, 1990), and elephantimorphs (Ekdale, 2011).

The morphology of the stapes varies significantly among species of placental mammals (e.g., as illustrated by Fleischer, 1973; Nummela, 1995; Solntseva, 2013). It has even been suspected once to reflect major divisions among Placentalia (Novacek \& Wyss, 1986), a view which has however been abandoned since (e.g., Patterson et al., 1992). Still, the phylogenetic signal carried by this bone might be important at least at other taxonomic levels. Pioneering and foundational work on stapes morphology include that of Doran (1878), Fleischer (1973), and Nummela (1995). In the semantic works of Doran (1878) and Fleischer (1973), the stapes of a dozen of extant artiodactyl taxa are described. Recent developments of micro-CT scan techniques have provided new tools to investigate the ear region of fossil mammals, giving an unprecedented access to its finest structures. During micro-CT scan investigation of the bony labyrinth of fossil artiodactyls one of the authors (MO) noticed numerous cases of post mortem preservation of the stapes in the bony labyrinth, a hollow cavity that shelters fluids and membranous parts of the inner ear organs. A systematic search for stapes trapped in the inner ear cavity was performed on a sample of 50 petrosals of extant and extinct artiodactyls. Among these 50 petrosal bones investigated, eight preserved this ossicle in the bony labyrinth space, indicating a not so rare occurrence of this case. Because it rests on the membrane of the fenestra vestibuli during life, the stapes may often fall within the bony labyrinth cavity when soft structures such as the tympanic membrane decay after death. In this work, we highlight the unexpected role that the bony labyrinth plays in the preservation of the stapes, the smallest and most fragile bone of the mammalian skeleton. We document the anatomy 
of fossil stapes of four extinct artiodactyl taxa: one Suidae, Microstonyx erymanthius; one Hippopotamoidea, Elomeryx borbonicus; one Helohyidae, ?Helohyus plicodon; and one undetermined Cainotheriidae. ?Helohyus plicodon from the Middle Eocene documents the oldest stapes known for the order Artiodactyla. "Intralabyrinthine stapes" have also been retrieved from bony labyrinths of four extant artiodactyls that had been chemically prepared: Hippopotamidae (Choeropsis; Hippopotamus), and Suoidea (Tayassu, Phacochoerus) and are included in this study. Measurements of the fossil stapes described are used to explore how the dimensions of several aspects of the stapes in Artiodactyla vary relative to one another and relative to the body mass and vestibule volume. Thanks to the availability of outgroup comparative data for the stapedial footplate, a comparison of the artiodactyl condition with that of other placentals could also be performed. The dimensions of the footplate area of the reconstructed stapes also allowed us to calculate low and high frequency limit estimates for the present artiodactyl sample, which adds to the wealth of information provided by this rarely preserved bone.

\section{MATERIAL AND METHODS}

\section{Material}

Over 50 petrosals of artiodactyls investigated, four fossil and four extant specimens yielded intralabyrinthine stapes. The stapes of the dichobunoid ?Helohyus plicodon is described from the virtual reconstruction of the right in situ bony labyrinth of specimen AMNH 13079 from the Bridger Formation locality B5, Sweetwater County, Wyoming. The stapes of a small undetermined cainotheriid species is described from an isolated right petrosal (UM PDS 3352) from Pech Desse, Quercy, France (MP 28, Late Oligocene, BiochroM'97). That of the hippopotamoid Elomeryx borbonicus is known from a right isolated petrosal (MHNL H 67) from Saint Henri, Bouches du Rhône (MP 26, early Late Oligocene). The stapes of Microstonyx erymanthius is documented from the interior of the bony labyrinth endocast of the mechanically prepared petrosal MNHN.F.MAR3299 illustrated by Orliac (2012: figs. 2-3) from the Late Miocene locality of Maragheh, Iran. Intralabyrinthine stapes have also been retrieved from bony labyrinths of four extant artiodactyls that had been chemically prepared for zoology collections: two hippopotamids Choeropsis liberiensis (UPPal-M09-5005a) and Hippopotamus amphibius (AMNH-M 24289), and two suoids Tayassu tajaccu (UM N03) and Phacochoerus sp. (AMNH unknown number).

\section{CT scanning and digital endocast extraction}

The specimens were scanned using either the high resolution GE phoenix|vtome|x s240 industrial micro-CT scanner at the American Museum of Natural History (New York), the Skyscan 1076 in vivo CT scanner at the ISE-M (UM), or the Viscom X8050-16 CT scanner at the IPHEP. Specimen numbers, CT scan institutions and resolution of each scan is summarized in Table 1. We extracted the digital endocasts of the bony labyrinths and the stapes using the segmentation tools of AVIZO 6.3 (Visualization Sciences Group) and calculated volumes by surface integration. The segmentation process was performed slice-by-slice manually with the limited range only option of the brush tool of AVIZO 6.3. We segmented the vestibules and semicircular canals in two separate label fields to estimate these volumes separately. The resolution of the CT scan data is, for most specimens, sufficient but not optimal to reconstruct an object as small as the stapes. Besides, taphonomic bias such as recrystallization and partial preservation sometimes led us to use different thresholds to reconstruct as much of the structure as possible. Using different thresholds might impact slightly the thickness of some reconstructed parts (Gunz et al., 2012) such as the crura (see Fig. 1) that are very thin. However, the general picture and the measured proportions of the stapes are preserved and reliable, except for one specimen (Elomeryx) whose footplate is possibly uncomplete and has been removed from some analyses (see Results). To minimize reconstruction bias, for all specimens of this study, the surface rendering was performed with the "none" smoothing type option.

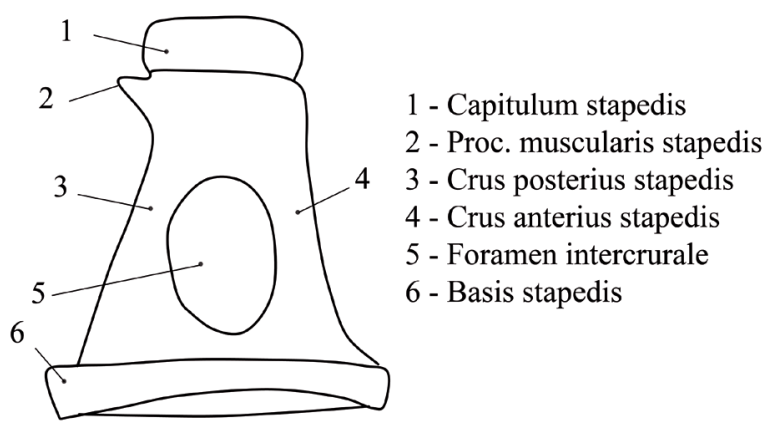

Figure 1. Illustration of stapes morphology following the nomenclature of Fleisher (1973).

$\begin{array}{llllll}\begin{array}{l}\text { suprafamilial } \\ \text { classification }\end{array} & \text { taxon } & \text { specimen number } & \text { side } & \begin{array}{l}\text { CT scan } \\ \text { institution }\end{array} & \begin{array}{l}\text { voxel size } \\ (\mu \mathrm{m})\end{array} \\ \text { Dichobunoidea } & \text { ?Helohyus plicodon } & \text { USNM 13079 } & \text { right } & \text { AMNH } & 61.66 \\ & \text { Cainotheriidae indet } & \text { PDS 3352 } & \text { right } & \text { UM } & 35.84 \\ \text { Hippopotamoidea } & \begin{array}{l}\text { Elomeryx borbonicus } \\ \text { Choeropsis liberiensis }\end{array} & \text { MHNL H 67 } & \text { right } & \text { UM } & 35.84 \\ & \text { Hippopotamus amphibius } & \text { AMNH-M 24289 } & \text { left } & \text { AMNH } & 120 \\ \text { Suoidea } & \text { Tayassu tajacu } & \text { UM N03 } & \text { right } & \text { UM } & 35.81 \\ \text { Suoidea } & \text { Microstonyx erymanthius } & \text { MNHN MAR3299 } & \text { right } & \text { UM } & 35.81 \\ \text { Suoidea } & \text { Phacochoerus } & \text { AMNH-M } & \text { left } & \text { AMNH } & 63.94\end{array}$

Table 1. Specimen related and technical parameters. For institution acronyms, see Materials and Methods. 


\section{Measurements}

We made linear measurements from the inner ear model using the 3-D measurement tool of AVIZO 6.3. The "vestibule volume" includes the semicircular canals but not the vestibular aqueduct. Measurements of the fossil stapes described here are provided in Table 2.

Relationships between the dimensions of several aspects of the stapes or of one stapedial dimension relative to body mass and vestibule volume were investigated through $\log / \log$ linear regression analyses calculated with Past (Hammer et al., 2001). When the relation was not found to be significant, we subsequently verified if it may however be otherwise when phylogenetic effects are considered. This was done using the ages of divergence and a pattern of relationships constructed from Gatesy et al. (2013) in order to perform Phylogenetic Independent Contrasts PICS (Felsenstein, 1985) with Mesquite module PDAP version 1.14 (Maddison \& Maddison, 2009, Midford, Garland \& Maddison, 2008). The cladogram used for this analysis and the branch lengths used are provided in Supplementary Online Material (.nex file).

For a comparison of the variation of the stapes dimensions relative to body mass with taxa outside Artiodactyla, data on the stapedial footplate dimensions in various placentals have been taken from Fleischer (1973; only specimens with non-ambiguous specific attribution have been considered here; all measurements and sources for body masses are indicated in Supplementary Online Material). Body mass estimates for fossil artiodactyl taxa have been calculated from total skull length estimates for the small-sized cainotheriid species using Janis (1990) equation and from astragalus dimensions for Elomeryx borbonicus (based on four specimens from St Henri, using the equation of Martinez \& Sudre, 1995). Body mass estimates for Microstonyx erymanthius were taken from the NOW database (Fortelius 2013), and estimates for ?Helohyus plicodon was taken from Alroy (1998).

\section{Abbreviations for collections and institutions}

AMNH, American Museum of Natural History, New York, USA; IPHEP, Institut de Paléoprimatologie, Paléontologie humaine : Evolution et Paléoenvironnements, Poitiers, France; MHNL, Muséum d'Histoire Naturelle de Lyon, Lyon, France ; MNHN, Muséum National d'Histoire Naturelle, Paris, France; UM, Université de Montpellier, Montpellier, France.

\section{DESCRIPTIONS}

The stapes consists of three parts: the head or capitulum, the shaft or body, divided in two crura (the anterior crus and the posterior crus), and the footplate (Fig. 1). The head of the stapes connects to the long arm of the incus, and the footplate of the stapes is kept in the fenestra vestibuli (oval window) of the petrosal with the help of a ring-shaped ligament. The musculus stapedius is attached to the processus muscularis stapedis (Proc. muscularis stapedis), lying in the area of the posterior wall of the tympanum. The shaft of the stapes presents a central cavity which provides passageway, at least in embryos, to the stapedial artery: the foramen intercrurale.

We assume in our sample, that a stapes trapped in a right bony labyrinth is a right stapes (Table 1). Based on illustrations of several mammalian stapes (Fleischer, 1973), it appears that the Proc. muscularis stapedis is located on the posterior crus. This criteria was primarily used to orientate the few stapes of our sample for which this process could be identified. In our sample, the stapes is asymmetrical, with a crus slenderer than the other. The foramen intercrurale is also wider on one face than the other. On illustrations sourced for extant mammals (Fleischer, 1973; Nummela, 1995) the slender crus can either be the anterior or the posterior one. For the illustrated ungulate mammals (artiodactyls and perissodactyls), however, the slender crus is always the anterior one. We therefore assume here that it is also always the case in artiodactyls. This criterion helps us to orientate the stapes when the Proc. muscularis stapedis could not be identified.

The stapes can be fragile, light, and hollow in some taxa (e.g., Rodentia, Chiroptera), and massive and compact in others (e.g. Carnivora, Cetacea). The stapes of the fossil artiodactyls documented in this study are lightly built; they show a wide range of morphologies but all present a wide foramen intercrurale between the two crura. In some taxa, this foramen is clearly larger on the lateral side of the bone, this is the case in E. borbonicus, H. amphibius, T. tajaccu, and Phacochoerus $\mathrm{sp}$. This character might be an artefact due to a difference of preservation of the bone on the lateral face. A difference of diameter of the foramen intercrurale between both faces is however also observed in other placental mammals (Fleischer, 1973). The outlines in lateral/medial views is triangular in ?H. plicodon, the Cainotheriidae indet., and C. liberiensis, whereas

\begin{tabular}{lccccccc}
\multicolumn{1}{c}{ taxon } & $\begin{array}{c}\text { fenestra } \\
\text { vestibuli } \\
(\mathrm{L} ; \mathrm{W})\end{array}$ & $\begin{array}{c}\text { stapes } \\
\text { length }\end{array}$ & $\begin{array}{c}\text { footplate } \\
(\mathrm{L} ; \mathrm{W})\end{array}$ & $\begin{array}{c}\text { footplate } \\
\text { ratio }\end{array}$ & $\begin{array}{c}\text { foramen } \\
\text { intercrurale } \\
(\mathrm{L} ; \mathrm{W})\end{array}$ & $\begin{array}{c}\text { estimated } \\
\text { bodymass }\end{array}$ & $\begin{array}{c}\text { vestibule } \\
\text { volume }\end{array}$ \\
?H. plicodon & $1.29 ; 0.91$ & 0.95 & $0.96 ; 0.59$ & 1.63 & $0.46 ; 0.51$ & 5000 & 8.24 \\
Cainotheriidae. & $1.34 ; 0.82$ & 1.21 & $1.17 ; 0.75$ & 1.56 & $0.77 ; 0.66$ & 1000 & 8.92 \\
E. borbonicus & $3.09 ; 1.62$ & 2.5 & $2.16 ; 0.95$ & 2.27 & $1.63 ; 1.07$ & 105500 & 44.69 \\
Hi. amphibius & $4.46 ; 3.40$ & 3.7 & $3.68 ; 2.36$ & 1.56 & $1.02 ; 0.78$ & 1850000 & 398.56 \\
C. liberiensis & $3.17 ; 1.84$ & 2.69 & $2.83 ; 1.58$ & 1.79 & $1.61 ; 1.36$ & 215000 & 155.5 \\
T. tajacu & $1.65 ; 0.9$ & 1.68 & $1.65 ; 0.86$ & 1.86 & $0.86 ; 0.67$ & 22000 & 27.2 \\
Phacochoerus sp. & $2.29 ; 1.19$ & 2.26 & $1.93 ; 1.07$ & 1.80 & $1.26 ; 0.93$ & 75000 & 51.38 \\
M. erymanthius & $2.29 ; 1.65$ & 2.2 & $2.06 ; 1.08$ & 1.90 & $1.5 ; 1.14$ & 270000 & 51.38
\end{tabular}

Table 2. Measurements of stapes and bony labyrinth of associated petrosal, and body mass estimates of artiodactyl taxa described in the present study. Sources for body mass estimates are provided in the material and method section. All linear measures in mm, body mass in g, volume in mm ${ }^{3}$. Abbreviations: L refers to length and $\mathrm{W}$ refers to width. 
it is more quadrangular in E. borbonicus, H. amphibius and the suoid species. This difference in shape is mainly due to differences in the antero-posterior width of the head of the stapes capitulum. Half of the stapes of our sample are asymmetrical. As in the case of Helohyus, the two hippopotamid species, and Tayassu, where one crus is thicker than the other (Fig. 2). The internal surface of the crura is concave in all the specimens investigated. The Proc. muscularis stapedis can be identified on all the stapes except for the two extant hippos. In our sample, the distinction between the capitulum of the stapes and the crura is not visible (Fig. 2). This could primarily be due to the less-than-optimal resolution of the reconstructions.
However, in its descriptions of artiodactyl stapes, Fleischer (1973) mentions the lack of demarcation of the capitulum in Sus and in Hippopotamus, and a weak demarcation in Camelus. In turn, according to the same author, the demarcation between the capitulum and the crura is well marked in the Ruminantia Capreolus and Giraffa. The footplates of our artiodactyl sample are oblong with a ratio comprised between 1.56 and 2.27 for the different taxa. Elomeryx borbonicus is remarkable by the slenderness of its footplate (ratio=2.27), although part of it might be missing. Suoidea show a large head compared to the size of the footplate. This is particularly visible in dorsal and posterior views in Fig. 2. Also, the width of the crura is large
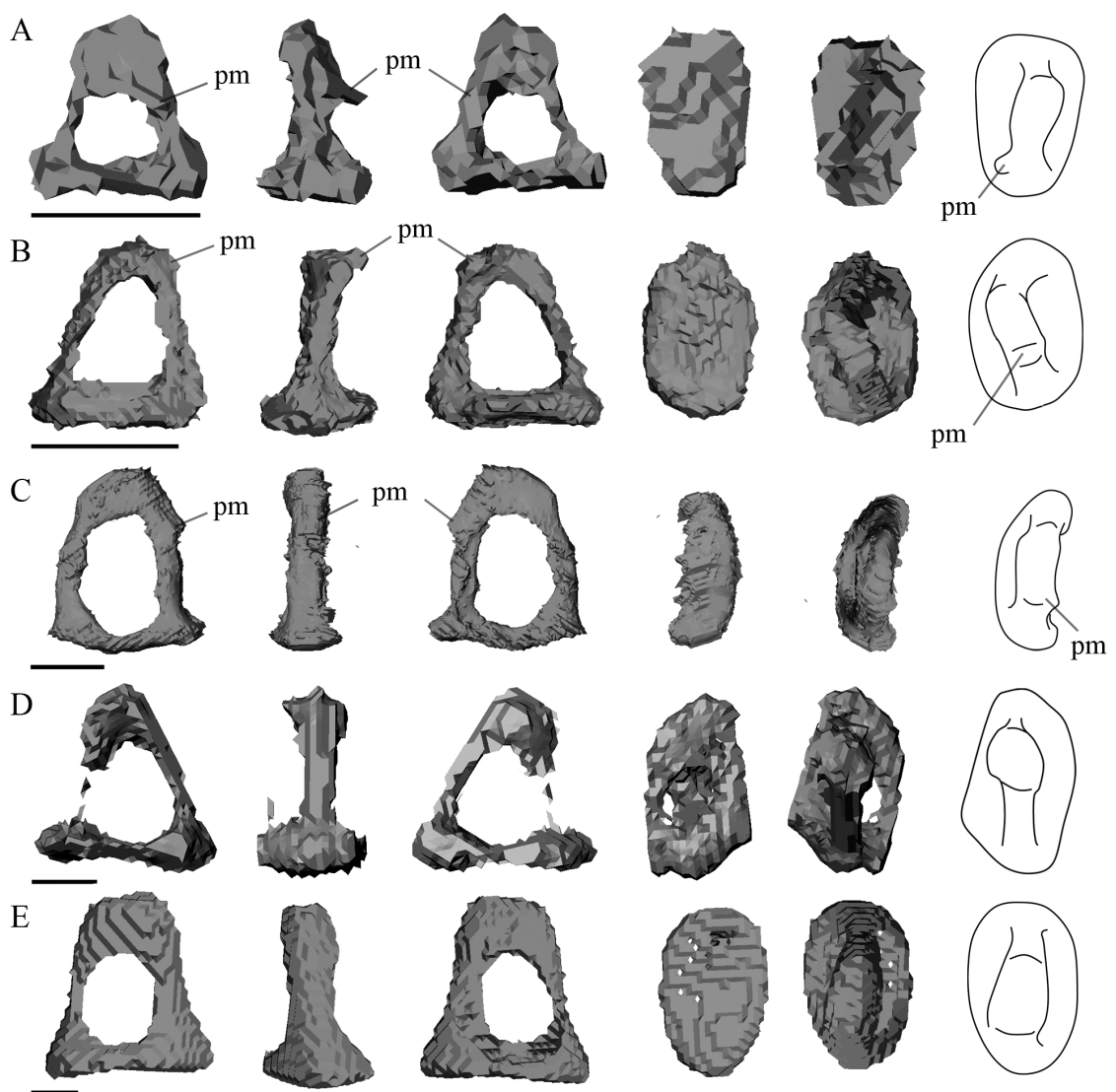

F
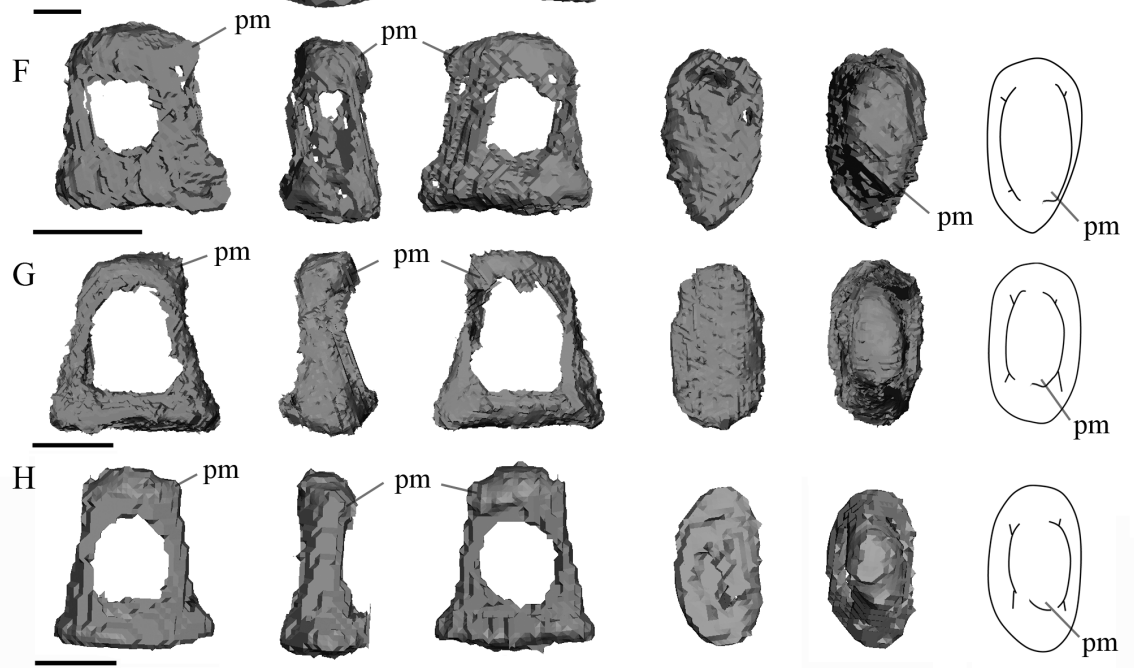

Figure 2. 3D stapes model reconstructions of Helohyus plicodon (right) (A); Cainotherium sp. (right) (B); Elomeryx borbonicus (right) (C); Choeropsis liberiensis (right) (D); Hippopotamus amphibius (left mirror view) (E); Tayassu tajacu (right) (F); Microstonyx erymanthius (G); Phacochoerus aegypticus (left mirror view) $(\mathbf{H})$, in from left to right medial, posterior, lateral, ventral, and dorsal views. Abbreviation: pm, Proc. muscularis stapedis. Scale bar $=1$ mm. 
relative to the width of the footplate and compared to the other taxa of our sample (visible in lateral view Fig. 2).

\section{METRIC ANALYSES}

Analyses of relationships between linear measurements taken on the stapes within our artiodactyl sample indicate that the length of the stapedial footplate varies almost isometrically with the length of the stapes (Fig. 3A, Table 2). The same is also true for the footplate width relative to the footplate length, and for the stapes length relative to the vestibule volume (Fig. 3B-C, Table 2). In contrast, the stapes length is clearly negatively allometrically correlated to the body mass (Fig. 3D, Table 2; NB: considering body mass as a three-dimensional variable, the scaling exponent should be $\sim 0.333$ to reach isometry, whereas it is 0.196 in our analysis).

Concerning the footplate dimensions, we have been able to gather a large sample including our data in artiodactyls and the measurements given by Fleischer (1973) in a number of other placentals and four additional artiodactyl specimens. It includes data for 12 artiodactyl individuals belonging to 11 different species and for 26 non-artiodactyl individuals (Supplementary Online Material). The footplate length and width are both clearly negatively allometric to body mass in this sample (i.e., slope less than one third; see above) (note that, as should be expected, similar results are obtained when plotting the footplate area against the body mass). Interestingly, artiodactyls appear to plot separately from most other placentals (Fig. 4A-B) for both the footplate length and width. The artiodactyl regression line actually indeed differs clearly from the regression line calculated for the sample of other placentals (non-Artiodactyla placentals). Both footplate length and width fit to a regression line that corresponds to a relatively smaller footplate in comparison with the non-Artiodactyla placentals regression line (Fig. 4A-B). The few placental taxa plotting close to the artiodactyl regression line for both length and width of the footplate include the perissodactyls Tapirus and Equus, the capybara and the aardvark.

Finally, the footplate ratio shows no significant relationship to the stapes length in our artiodactyl sample $\left(\mathrm{R}^{2}=0.0619\right.$, $\mathrm{p}=0.55)$, whether it includes or not Elomeryx whose footplate may be missing some lateral part. When taking phylogenetic effects into account (PICs analysis; see Material and Methods),
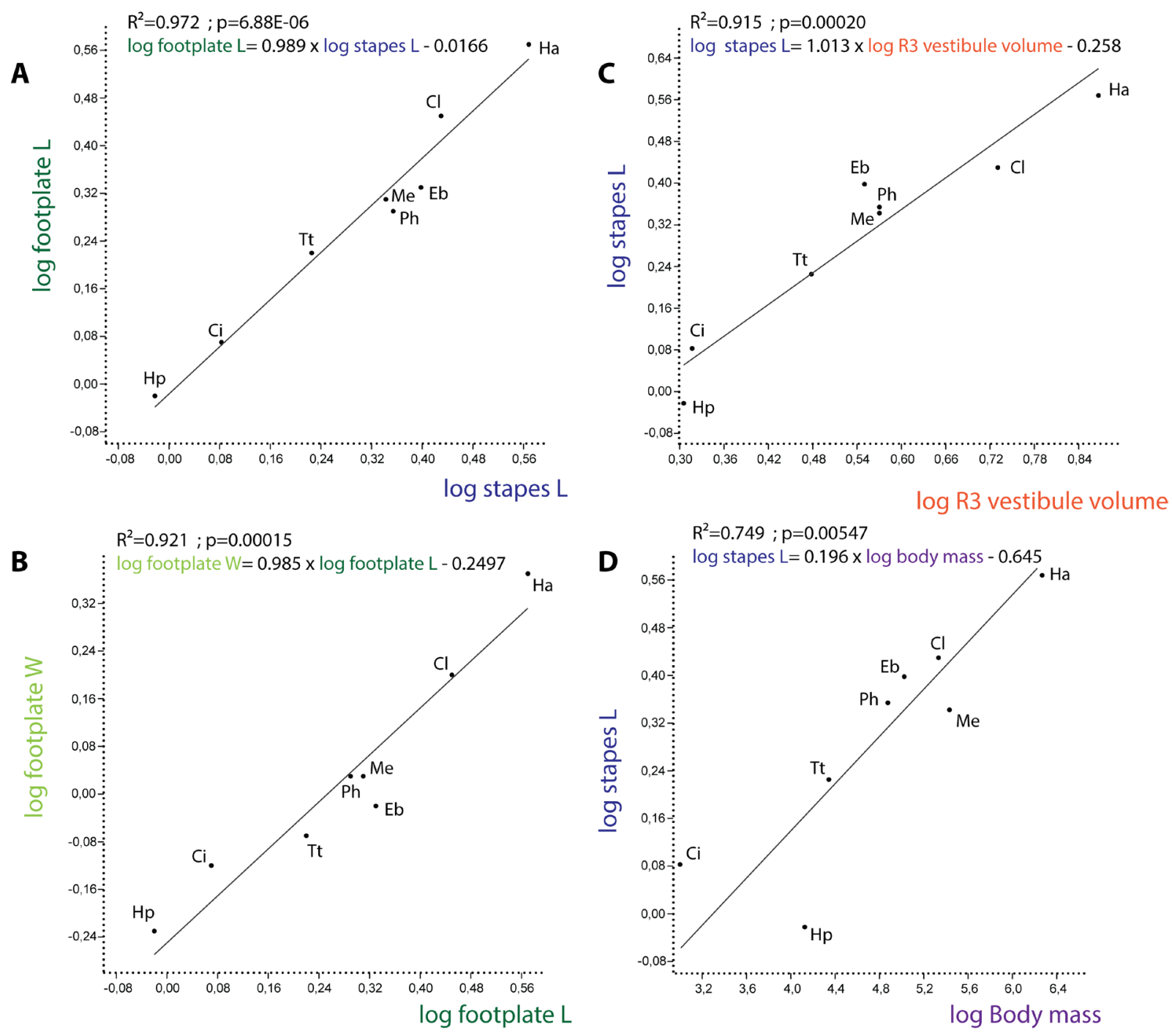

Figure 3. Regression analyses between stapes measurements, cube root of vestibule volume and body mass (see data in Table 2) for a sample of eight artiodactyl species. Abbreviations: Ci, Cainotheriidae indet.; Cl, Choeropsis liberiensis; Eb, Elomeryx borbonicus; Hp, ?Helohyus plicodon; Ha, Hippopotamus amphibius; Me, Microstonyx erymanthius; $\mathrm{Ph}$, Phacochoerus; Tt, Tayassu tajacu. 
the analysis provides a similar result $\left(\mathrm{R}^{2}=0.14 ; \mathrm{p}=0.36\right)$ (Supplementary Online Material). This shows that the variation of the footplate ratio is clearly not dependent on the stapes length in our sample. Instead, there might be some phylogenetic influence on the footplate ratio because the highest values $(E$. borbonicus excepted) are found in the suoid clade (Tayassu (Microstonyx, Phacochoerus)) (values between 1.80 and 1.90). Furthermore, the values of the footplate ratio in artiodactyls (range $=1.56-2.27$ ) are close to the mean of our placental sample excluding artiodactyls (mean $=0.55$ ). Therefore, though artiodactyls may be distinguished from lipotyphlan taxa which show a very high ratio $(\geq 2.50)$, their footplate ratio is not diagnostic when compared to most other placentals in our sample (Supplementary Online Material; Excel file).

\section{DISCUSSION}

\section{Frequency and location of « intralabyrinthine " preserva- tion of stapes}

Cases of fossil stapes retrieved from intra-labyrinth space occur in several placental groups, but most remain unpublished until now. While several cases have been observed at least in primates (Benoit et al., 2013; R. Lebrun pers. comm.), notoungulates, litopterns, xenarthrans (G. Billet pers. observ.), and proboscideans (A. Schmitt pers. comm.), intralabyrinthine preservation of stapes has not been reported from studies based on a rather wide sample of fossil perissodactyls including equoids (L. Danilo pers. comm.) and rhinocerotids (M. J. Orliac unpublished data).

The stapes rests on the membrane of the fenestra vestibuli during life; it is connected to this fenestra by an annular ligament (Fleischer, 1973). Comparison of the stapedial footplate dimensions to the dimensions of the fenestra vestibuli indicates that in most cases in our sample, the latter is much larger than the former (Table 2), making it easy for the stapes to fall in the inner ear space after the soft tissue decays. Artiodactyls present an ossified bulla, and, as such, preservation of in situ stapes, or stapes trapped in the middle ear space, within the bulla would be expected. However, for artiodactyls of our sample that did preserve the auditory bulla, no stapes was recovered in the middle ear cavity but they were recovered in the bony labyrinth of the inner ear. Besides, stapes were recovered more frequently from isolated petrosal (five cases) than from in situ petrosals (two cases). This observation suggests that once it is trapped in the bony labyrinth, a stapes has little chance to fall out of it, even if the cranial remains are displaced/moved/ after death, most probably because of the small size of the fenestrae compared to the dimensions of the stapes (Fig. 5). In half of the cases, the stapes are preserved in the ampullar area (e.g., ?Heloyus, Fig. 5A-C; Microstonyx, Fig. 5J-L); it is otherwise preserved in the elliptical/spherical recesses (e.g., Elomeryx, Fig. 5D-F; Choeropsis) or in the space of the basal turn of the cochlea (e.g., Cainotheriidae indet, Fig. 5G-I).

\section{Stapes dimensions in artiodactyls}

Regression analyses on our small artiodactyl sample indicate close isometry between several dimensions of the stapes such as its length and the length and width of its footplate, which denotes that these dimensions can be directly compared using ratios. Moreover, the stapes length is also closely isometrically correlated with the vestibule volume of the bony labyrinth in our sample, whereas it is clearly negatively allometrically correlated to the body mass. This indicates that the stapes and vestibule may present a similar slower growth pace relative to the body mass in artiodactyls. This is not surprising as strong negative allometry has already been shown for both the middle-ear ossicles and the bony labyrinth of the inner ear relative to other cranial elements and/or body mass (e.g., Nummela ,1995; Luo et al., 2001; Nummela \& Sánchez-Villagra, 2006; Spoor et al., 2007; Billet et al., 2015).

In addition, comparison of stapedial footplate dimensions relative to body mass between artiodactyls and other placentals demonstrate that the former group may possess relatively small stapes (or at least small stapedial footplates). Interestingly, the two perissodactyls included in our sample also show a similar pattern to artiodactyls. The relative small size of the stapedial footplate might therefore be a synapomorphy of Euungulata, the clade that gathers Artiodactyla and Perissodactyla (Asher
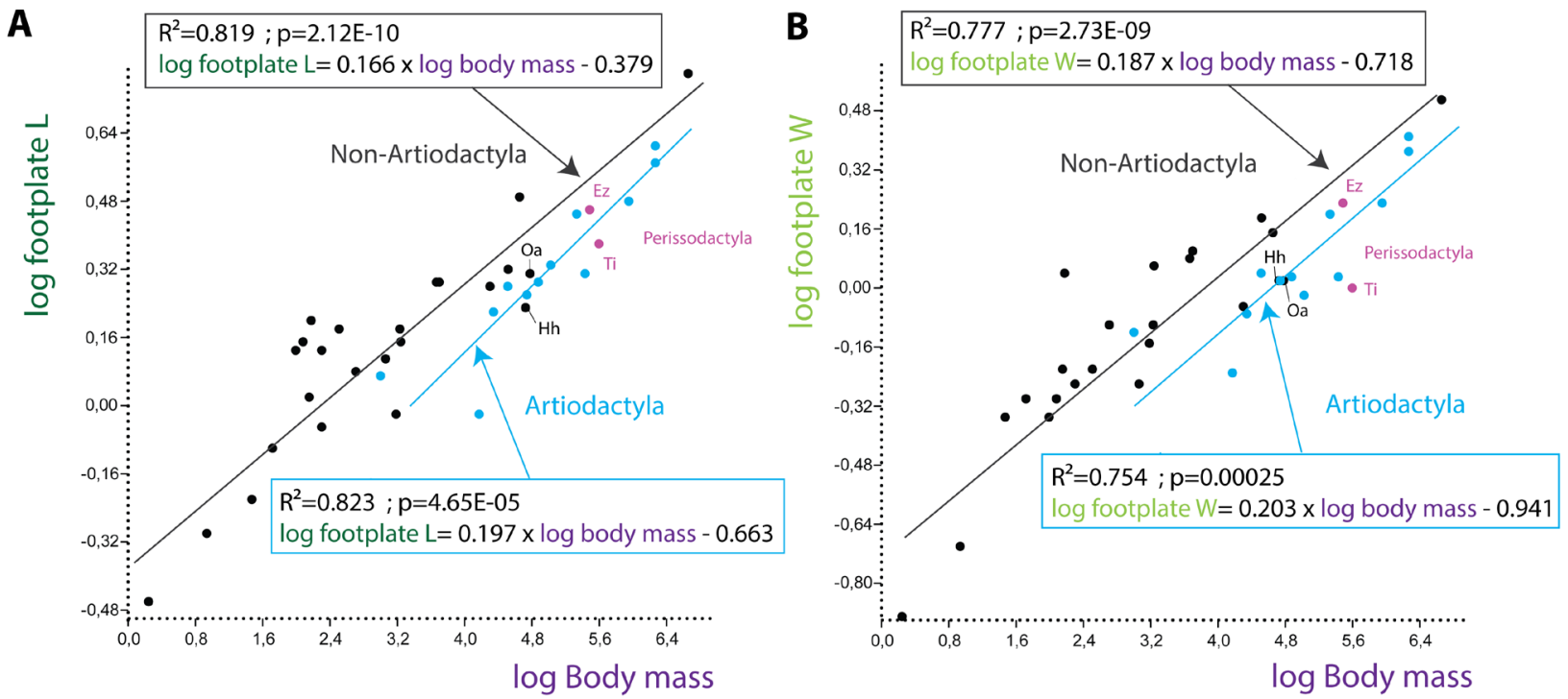

Figure 4. Regression analyses between stapedial footplate dimensions (A, footplate length; $\mathbf{B}$, footplate width) and the body mass in a sample of 11 artiodactyl species (12 individuals) and 26 non-artiodactyl placental species (data provided in Supplementary Online Material). Abbreviations: Ez, Equus zebra; Hh, Hydrochoerus hydrochaeris; Oa, Orycteropus afer; Ti, Tapirus indicus. 
\& Helgen, 2010). Moreover, as the stapedial footplate rests on the membrane of the fenestra vestibuli during life, the dimensions of this fenestra may also be reduced in euungulates in comparison to other placentals. This might also be connected to the relative light weight of the malleus and incus in several artiodactyls and perissodactyls (Nummela, 1995). These preliminary results, which may have significant phylogenetic and potential functional implications (see below hearing estimates based on the footplate area), thus clearly deserve to be investigated in larger samples of placentals in the future.

Finally, we have also shown, based on our small artiodactyl sample, that footplate shape is probably not influenced by allometry in these ungulates. Therefore, footplate shape may be examined in order to detect phylogenetically significant differences between artiodactyl groups. Though a larger sampling is required to confirm it, an elongated stapedial footplate (high footplate ratio) may for example constitute a synapomorphy of the clade Suoidea.

\section{Stapes morphology of Hippopotamidae and amphibious communication}

In fully aquatic and semi-aquatic mammals, like cetaceans, sirenians and phocids, underwater hearing implies a modification of the ossicular chain morphology and mass, in relation to bone conduction of sounds (for review see Nummela, 2008). Most of the morphological modifications described in relation to the adaptation of underwater hearing concern the malleus and incus (larger and denser than in terrestrial mammals). Yet, the relation of the mass of the stapes to that of the malleus plus incus is very close to isometry (Nummela, 1995) and the stapes has to be solid enough to stand the inertial force produced by the swing induced by the malleus and incus. The available sample of stapes illustrated for aquatic and semi aquatic mammals show that the stapes of these taxa is massive and presents wide and thick crura, as well as a very small or closed foramen intercrurale (e.g., Phocaena, Balaenoptera, Manatus, Arctocephalus, Otaria, Phoca; see Doran, 1878:P1. 59, 626-63; Fleisher, 1973:figs 36, 41, 52;).

Hippos are semi aquatic mammals, spending most of their day in the water but feeding mostly on land. With its head in an "amphibious position" (eyes, nostrils and ears above water, mouth and throat below), $H$. amphibius can respond to sounds emitted underwater: with the ears out of the water, it is able to hear directionally in air and water simultaneously (Barklow, 2004). Virtually no information is available for $C$. liberiensis regarding its ability to hear sound directionally underwater, but the morphology of its petrosal bone, with a pachyostotic tegmen tympani also suggests a specialization of sound perception pathway (O'Leary et al., 2012, Orliac et al., 2014). The way sound waves are transmitted from water to the inner ear underwater in hippos is still unclear, but it most probably implies bone conduction (Barklow, 2004). A few stapes of H. amphibius are illustrated in Doran (1878) and Fleischer (1973). Doran (1878) mentions that the three specimens of $H$. amphibius he could observe present a large foramen intercrurale. It is also the case of the specimen illustrated by Fleischer (1973) and for the two specimen of Hippopotamidae illustrated in this work. In $H$. amphibius, as well as in $C$. liberiensis, the crura are slender when compared to the aquatic and semi aquatic mammals that perform bone conduction cited above. Despite their ability to directionally hear sound underwater, hippos do not show the common morphological modifications of the stapes found in other amphibious mammals.

\section{Auditory capabilities of extant and extinct species}

Correlations between middle ear ossicles size and shape, and auditory capacities have been demonstrated in therian mammals (e.g., Rosowski \& Graybeal, 1991; Hemilä et al., 1995; Mason, 2004; Nummela \& Sanchez-Villagra, 2006; Nummela et al., 2007). Rosowski \& Graybeal (1991:fig. 8) used stapedial footplate area to estimate the audible hearing range of the extinct mammaliaform Morganucodon. This correlation has subsequently been used to propose estimates for early placental mammals (Meng \& Fox, 1995). We use here the equations of Rosowski \& Graybeal (1991) to calculate low and high frequency limit estimates of our artiodactyl sample based on the footplate area of the reconstructed stapes. Results are provided in Table 3 .

The lowest values for low frequency limit estimates are found in extant hippos, $H$. amphibius (low limit $=0.05 \mathrm{kHz}$, high limit $=15.77 \mathrm{kHz}$ ) and $C$. liberiensis (low limit $=0.10$ $\mathrm{kHz}$, high limit $=20.57 \mathrm{kHz}$ ). Hearing limits for these taxa have, to our knowledge, never been determined. The extant Hippopotamus amphibius communicates using a variety of sounds, including surface calls with peak frequency at $0.205 \pm 0.188$ $\mathrm{kHz}$ on the surface (Barklow, 2004), a value consistent with

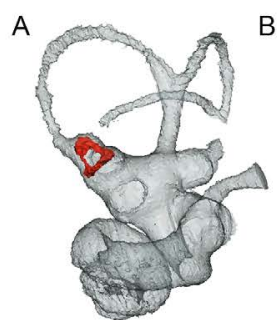

D

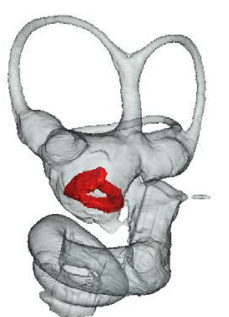

G

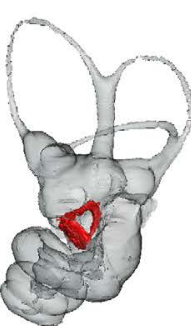

$J$

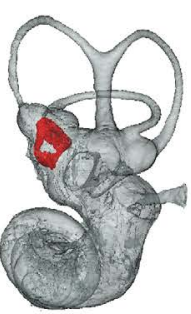

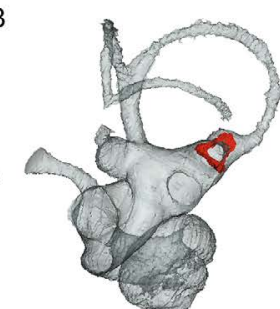

E

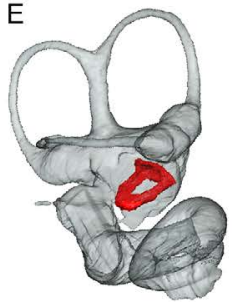

$\mathrm{H}$

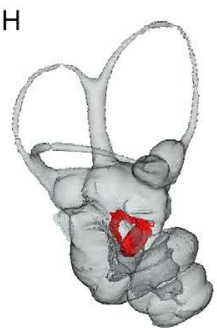

K

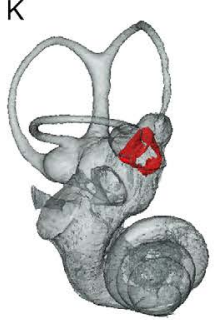

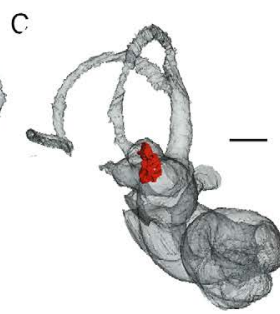

F

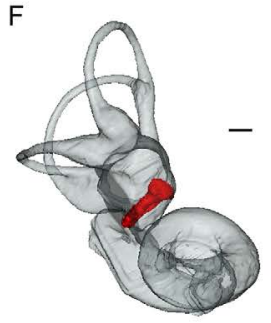

I

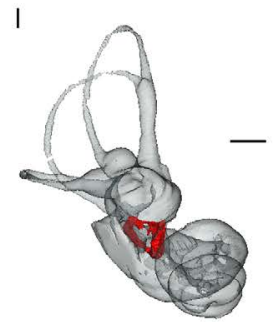

L

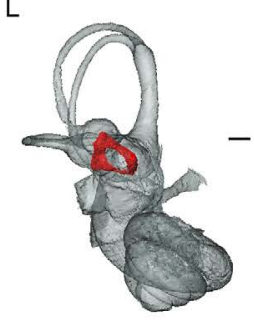

Figure 5. Bony labyrinth and associated stapes of extinct artiodactyl taxa: ?Helohyus plicodon (A-C); Elomeryx borbonicus (D-F); Cainotheriidae indet (G-I); Microstonyx erymanthius (J-L) in anteromedial (A,D,G,J), posterolateral $(\mathrm{B}, \mathrm{E}, \mathrm{H}, \mathrm{K})$, and ventromedial $(\mathrm{C}, \mathrm{F}, \mathrm{I}, \mathrm{L})$ views. Scale bar $=1 \mathrm{~mm}$. 


\section{CONCLUSIONS}

\begin{tabular}{|c|c|c|c|}
\hline taxon & $\begin{array}{c}\text { footplate } \\
\text { area }\end{array}$ & $\begin{array}{c}\text { low } \\
\text { frequency } \\
\text { limit }\end{array}$ & $\begin{array}{c}\text { high } \\
\text { frequency } \\
\text { limit }\end{array}$ \\
\hline ?H. plicodon & 0.44 & 0.98 & 47.01 \\
\hline Cainotheriidae indet & 0.69 & 0.6 & 39.46 \\
\hline E. borbonicus & 1.61 & 0.24 & 28.09 \\
\hline Hi. amphibius & 6.82 & 0.05 & 15.77 \\
\hline C. liberiensis & 3.51 & 0.10 & 20.57 \\
\hline T. tajacu & 1.11 & 0.36 & 32.56 \\
\hline Phacochoerus sp. & 1.62 & 0.23 & 28.02 \\
\hline M. erymanthius & 1.75 & 0.22 & 27.20 \\
\hline Diacodexis ilicis* & 0.58 & 0.73 & 42.24 \\
\hline
\end{tabular}

Table 3. Audible hearing range estimates (expressed in $\mathrm{kHz}$ at $60 \mathrm{~dB} \mathrm{SPL}$ re: $20 \mathrm{uPa}$ ) for the artiodactyl sample of the present study based on stapedial footplate area (in $\mathrm{mm} 2$ ). Low and high frequency limit estimates are calculated after the equations of Rosowski \& Graybeal (1991). * footplate area for $D$. ilicis calculated after the dimensions of the fenestra vestibuli.

the hearing range estimated here for this taxon based on stapes dimensions. H. amphibius also communicates underwater and produce sounds underwater (Barklow, 2004). The mean peak frequency measured underwater equals $2.087 \pm 1.487 \mathrm{kHz}$ (Barklow, 2004), a value which is also consistent with the present estimates. Interestingly, the values found for the extinct smaller hippopotamoid Elomeryx borbonicus (low limit $=0.24$ $\mathrm{kHz}$, high limit $=28.09 \mathrm{kHz}$ ) are higher than those calculated for extant hippos and correspond to the hearing range estimated for suoid taxa (Table 3). The estimates calculated here for suoid taxa are close to the hearing range of the extant suid Sus scrofa at $60 \mathrm{~dB}$ (low limit $=0.04 \mathrm{kHz}$, high limit $=40.5 \mathrm{kHz}$, Heffner \& Heffner, 1990), although low frequency limits seem to be overestimated. The small Paleogene artiodactyls ?H. plicodon and the undetermined cainotheriid taxon are the smallest taxa of our sample (see Supplementary Online Material). Their calculated audible hearing range show high upper and lower limits. Their low limit values are superior to that estimated for Diacodexis ilicis based on cochlear coiling $(0.543 \mathrm{kHz}$, Orliac et al., 2012); but closer values are found when Rosowski \& Graybeal (1991) equation is used for D. ilicis (Table 3). Finding higher limit estimates for smaller taxa is not surprising as the audible range correlates with interaural distance for taxa using binaural cues (Heffner \& Heffner, 1992, 2008) and taxa with small heads and close set ears will be able to hear higher frequencies than taxa with large heads. These results indicate that, based on their stapedial footplate area, ?H. plicodon and the undetermined cainotheriid taxon, were most probably not low frequency hearing specialists, and had hearing limits values congruent with their small size .

Footplate area allows calculating estimates of the audible hearing range of extinct taxa. This proxy would need to be complemented by other methods using measurements of the bony labyrinth such as power functions based on basiliar membrane length and cochlear canal coiling that show good correlations with hearing limits (West, 1985). As this work focuses on the morphology of the stapes, we chose to use measurements from the stapes only, and not to include data from the bony labyrinth to calculate low and high frequency limit estimates.
Fossil stapes are likely to be found in a wide array of bony labyrinth of mammals. In artiodactyls, we report a quite frequent occurrence of stapes fallen in the bony labyrinth after death and tissue decay. Stapes are either preserved in the ampulla, in the elliptical/spherical recesses, or in the basal turn of the cochlea. Artiodactyla stapes show diverse morphologies, and stapes are likely to carry potentially relevant phylogenetic characters.

Metric analyses show that, in our sample, the stapes length is closely isometric with the vestibule volume of the bony labyrinth, whereas it is strongly negatively allometric to body mass. Regression analyses between stapedial footplate dimensions and the body mass in a sample of placentals demonstrate that artiodactyls and perissodactyls may possess relatively small stapes compared to other placental mammals. These preliminary results achieved on a reduced sample show that stapedial morphology clearly deserves to be investigated in larger samples of placentals in the future.

\section{ACKNOWLEDGMENTS}

We first want to acknowledge R. O'Leary (AMNH), J. Meng (AMNH), D. Berthet (Musée des Confluences, Lyon), S. Jiquel (UM) for access to the collections they are in charge of. We are grateful to M. Hill (AMNH), F. Guy (IPHEP), and R. Lebrun (UM) for access to CT scan facilities in the American Museum of Natural History, New York, in the Université de Poitiers, France, and in the Universite de Montpellier, France, respectively. We are also grateful to L. Danilo, A. Schmitt (MNHN), and R. Lebrun for providing us with information about occurrences of stapes in the material they study. We also want to thank F. Lihoreau (UM) for body mass calculation of Elomeryx borbonicus. This work has been possible thanks to the high-resolution CT scanner facility of the AMNH funded by the NSF MR1-R2 0959384 to N. Landman, D. Ebel and D. Frost, and to the technical facilities of the Montpellier Rio Imaging platform (Montpellier, France) of the labEx CeMEB. We are grateful to the two anonymous reviewers for their fruitful comments. This is ISEM publication ISEM 2015-248.

\section{BIBLIOGRAPHY}

Allin, E. F., Hopson, J. A., 1992. Evolution of the auditory system in Synapsida ("mammal-like reptiles" and primitive mammals) as seen in the fossil record. In: Webster, D. B., Popper, A. N., Fay, R. R. (Eds), The evolutionary biology of hearing. Springer New York. pp. 587-614.

Alroy, J., 1998. Cope's Rule and the dynamics of body mass evolution in North American fossil mammals. Science 280, 731-734. doi:10.1126/science.280.5364.731

Archibald, J. D., 1979. Oldest known eutherian stapes and a marsupial petrosal bone from the Late Cretaceous of North America. Nature 281, 669-670. doi:10.1038/281669a0

Asher, R. J., Helgen, K. M., 2010. Nomenclature and placental mammal phylogeny. BMC Evolutionary Biology 10(1), 102. doi:10.1186/1471-2148-10-102

Barklow, W. E., 2004. Amphibious communication with sound in hippos, Hippopotamus amphibius. Animal Behaviour 68, 1125-1132. doi:10.1016/j.anbehav.2003.10.034

Benoit, J., E. M. Essid, W. Marzougui, H. Khayati Ammar, R. Lebrun, R. Tabuce, and L. Marivaux. 2013. New insights into the ear region anatomy and cranial blood supply of advanced stem 
Strepsirhini: evidence from three primate petrosals from the Eocene of Chambi, Tunisia. Journal of Human Evolution 65, 551-572. doi: 10.1016/j.jhevol.2013.06.014

Billet, G., Muizon, C., Schellhorn, R., Ruf, I., Ladevèze, S., Bergqvist, L. 2015. Petrosal and inner ear anatomy and allometry amongst specimens referred to Litopterna (Placentalia). Zoological Journal of the Linnean Society 173, 956-987. doi:10.1111/ zoj. 12219

BiochroM'97 (collectif), 1997. Synthèses et Tableaux de corrélations. In: Aguilar, J.-P., Legendre, S., Michaux, J. (Eds.), Actes du Congrès BiochroM'97. Mémoires et Travaux de l'École Pratique des Hautes Études, Institut de Montpellier, Montpellier, pp. 769-805.

Blanco, R. E., Rinderknecht, A., 2012. Fossil evidence of frequency range of hearing independent of body size in South American Pleistocene ground sloths (Mammalia, Xenarthra). Comptes Rendus Palevol 11(8), 549-554. doi:10.1016/j. crpv.2012.07.003

Crompton, A. W., Luo, Z., 1993. Relationships of the Liassic mammals Sinoconodon, Morganucodon oehleri, and Dinnetherium. In: S. Szalay, F., Novacek, M. J., McKenna, M. C. (Eds), Mammal Phylogeny. Springer New York, pp. 30-44. doi:10.1007/9781-4613-9249-1 4

Doran, A. H., 1878. XVIIII. Morphology of the Mammalian Ossicula auditûs. Transactions of the Linnean Society of London. 2nd Series: Zoology 1(7), 371-497. doi:10.1111/j.1096-3642.1878. tb00663.x

Ekdale, E. G., 2011. Morphological variation in the ear region of Pleistocene Elephantimorpha (Mammalia, Proboscidea) from central Texas. Journal of Morphology 272(4), 452-464. doi:10.1002/jmor.10924

Felsenstein, J. 1985. Phylogenies and the comparative method. American Naturalist 125, 1-15.

Fleischer, G., 1973. Studien am Skelett des Gehörorgans der Säugetiere, einschließlich des Menschen. Säugetierkundliche Mitteilungen 21, 131-239.

Fortelius, M. (coordinator), 2013. New and Old Worlds Database of Fossil Mammals (NOW). University of Helsinki. Available at: http://www.helsinki.fi/science/now/

Gatesy, J., Geisler, J. H., Chang, J., Buell, C., Berta, A., Meredith, R. W., Springer, M. S., McGowen, M. R., 2013. A phylogenetic blueprint for a modern whale. Molecular Phylogenetics and Evolution, 66(2), 479-506. doi:10.1016/j.ympev.2012.10.012

Gregory, W. K., 1920. On the structure and relations of Notharctus, an American Eocene primate. Memoirs of the AMNH 3, 45-243. Available at: http://hdl.handle.net/2246/5725

Gunz, P., Ramsier, M., Kuhrig, M., Hublin, J. J., Spoor, F., 2012. The mammalian bony labyrinth reconsidered, introducing a comprehensive geometric morphometric approach. Journal of Anatomy, 220(6), 529-543. doi:10.1111/j.14697580.2012.01493.x

Guth, C., 1957. Le stapes de quelques édentés fossiles. Mammalia 21(2), 121-124.

Guth, C., 1961. La région temporale des Édentés. Thèse de doctorat, Université de Paris, Imprimerie Jeanne d'Arc.

Hammer, Ø., Harper, D. A. T., Ryan, P. D. 2001 PAST: paleontological statistics software package for education and data analysis. Palaeontologia Electronica 4, 9. Available at http://palaeoelectronica.org/2001 1/past/issue1 01.htm

Heffner, R. S., Heffner, H. E. ., 1990. Hearing in domestic pigs (Sus scrofa) and goats (Capra hircus). Hearing Research 48(3), 231-240.

Heffner, R. S., Heffner, H. E., 1992. Evolution of sound localization in mammals. In: Webster, D. B., Popper, A. N., Fay, R. R. (Eds), The evolutionary biology of hearing. Springer, New York, pp. 691-715. doi:10.1007/978-1-4612-2784-7 43

Heffner, R. S., Heffner, H. E., 2008 High-frequency hearing. In: Dallos, P., Oertel, D., Hoy, R., (Eds), Handbook of the senses: audition. Elsevier, New York, pp. 55-60.

Hemilä, S., Nummela, S., Reuter, T., 1995. What middle ear parameters tell about impedance matching and high frequency hearing. Hearing Research, 85(1), 31-44. doi:10.1016/03785955(95)00031-X

Janis, C., 1990. Correlation of cranial and dental variables with body size in ungulates and macropodoids. In: Damuth, J., MacFadden, B. J., (Eds), Body size in mammalian paleobiology. Cambridge University Press, Cambridge, pp. 255-299.

Kermack, K.A., Mussett, F. Rigney, H. W., 1981. The skull of Morganucodon. Zoological Journal of the Linnean Society 71, 1-158. doi: 10.1111/j.1096-3642.1981.tb01127.x

Lancaster, W. C., 1990. The middle ear of the Archaeoceti. Journal of Vertebrate Paleontology 10(1), 117-127. doi:10.1080/027246 34.1990.10011795

Lillegraven, J. A., Krusat, G., 1991. Cranio-mandibular anatomy of Haldanodon exspectatus (Docodonta; Mammalia) from the Late Jurassic of Portugal and its implications to the evolution of mammalian characters. Rocky Mountain Geology 28(2), $39-138$

Luo, Z. X., Crompton, A. W., Sun, A. L., 2001. A new mammaliaform from the early Jurassic and evolution of mammalian characteristics. Science 292(5521), 1535-1540. doi: 10.1126/ science. 1058476

Luo, Z. X., 2011. Developmental patterns in Mesozoic evolution of mammal ears. Annual Review of Ecology, Evolution, and Systematics 42, 355-380. doi:10.1146/annurevecolsys-032511-142302

Maddison, W. P., Maddison, D. R., 2009. Mesquite: a modular system for evolutionary analysis. Version 2.71. Available at: http:// mesquiteproject.org

Martinez, J. N., Sudre, J., 1995. The astragalus of Paleogene artiodactyls: comparative morphology, variability and prediction of body mass. Lethaia 28(3), 197-209. doi:10.1111/j.1502-3931.1995.tb01423.x

Mason, M. J., 2004. Functional morphology of the middle ear in Chlorotalpa golden moles (Mammalia, Chrysochloridae): predictions from three models. Journal of Morphology 261, 162-174. doi:10.1002/jmor.10235

Meng, J., 1992. The stapes of Lambdopsalis bulla (Multituberculata) and transformational analyses on some stapedial features in Mammaliaformes. Journal of Vertebrate Paleontology 12(4), 459-471. doi:10.1080/02724634.1992.10011474

Meng, J., Fox, R. C., 1995. Osseous inner ear structures and hearing in early marsupials and placentals. Zoological Journal of the Linnean Society 115(1), 47-71. doi:10.1006/zjls.1995.0033

Miao D., Lillegraven, J. A., 1986. Discovery of three ear ossicles in a multituberculate mammal. National Geographic Research 2(4), 500-507.

Midford, P. E., Garland Jr, T., Maddison, W. P., 2008. PDAP package of Mesquite, version 1.14. Available at: http://mesquiteproject. org/pdap mesquite/

Moggi-Cecchi, J., Collard, M., 2002. A fossil stapes from Sterkfontein, South Africa, and the hearing capabilities of early hominids. Journal of Human Evolution 42(3), 259-265. doi:10.1006/ jhev.2001.0524

Novacek, M. J., Wyss, A., 1986. Origin and transformation of the mammalian stapes. Rocky Mountain Geology 24(special paper 3), 35-53. doi: 10.2113/gsrocky.24.special paper 3.35

Nummela, S., 1995. Scaling of the mammalian middle ear. Hearing Research 85(1), 18-30. doi:10.1016/0378-5955(95)00030-8

Nummela, S., 2008. Hearing in aquatic mammals. In Nummela, S., Thewissen, J. G. M. (Eds.), Sensory evolution on the threshold, adaptation in secondarily vertebrates. University of California Press, Berkley and Los Angeles, pp. 211-226.

Nummela, S., Sánchez-Villagra, M. R., 2006. Scaling of the marsupial middle ear and its functional significance. Journal of Zoology 270(2), 256-267. doi:10.1111/j.1469-7998.2006.00126.x

Nummela, S., Thewissen, J. G. M., Bajpai, S., Hussain, T., Kumar, K., 2007. Sound transmission in archaic and modern whales: anatomical adaptations for underwater hearing. The Anatomical Record 290(6), 716-733.

O'Leary, M. A., Patel, B. A., Coleman, M. N., 2012. Endocranial 
petrosal anatomy of Bothriogenys (Mammalia, Artiodactyla, Anthracotheriidae) and petrosal volume and density comparisons among aquatic and terrestrial artiodactyls and outgroups. Journal of Paleontology, 86, 44-50. doi: 10.1666/10-091.1

Orliac, M. J., 2012. The petrosal bone of extinct Suoidea (Mammalia, Artiodactyla). Journal of Systematic Palaeontology 11(8), 925-945. doi:10.1080/14772019.2012.704409

Orliac, M. J., Benoit, J., O'Leary, M. A., 2012. The inner ear of Diacodexis, the oldest artiodactyl mammal. Journal of Anatomy 221, 417-426. doi:10.1111/j.1469-7580.2012.01562.x

Orliac, M., Guy, F., Lebrun, R., 2014. Osteological connexions of the petrosal bone of the extant Hippopotamidae Hippopotamus amphibius and Choeropsis liberiensis. MorphoMuseuM, 1(1), e1, 1-6. doi:10.18563/m3.1.1.e1

Patterson, B., Segall, W., Turnbull, W. D., Gaudin, T. J., 1992. The ear region in xenarthrans (= Edentata, Mammalia). Part II. Pilosa (sloths, anteaters), palaeanodonts, and a miscellany. Fieldiana, Geology n.s. 24, 1-79.

Rosowski, J. J., Graybeal, A., 1991. What did Morganucodon hear? Zoological Journal of the Linnean Society 101(2), 131-168. doi: 10.1111/j.1096-3642.1991.tb00890.x
Ruf, I., Luo, Z. X., Martin, T., 2013. Reinvestigation of the basicranium of Haldanodon exspectatus (Mammaliaformes, Docodonta). Journal of Vertebrate Paleontology 33(2), 382-400. doi:10.10 80/02724634.2013.722575

Solntseva, G., 2013. Adaptive features of the middle ear of mammal in ontogeny. Acta Zoologica Bulgarica 65, 101-116.

Spoor, F., Garland Jr, T., Krovitz, G., Ryan, T. M., Silcox, M. T., Walker, A., 2007. The primate semicircular canal system and locomotion. Proceedings of the National Academy of Sciences, USA 104, 10 808-10 812. doi:10.1073/pnas.0704250104

West, C. D., 1985. The relationship of the spiral turns of the cochlea and the length of the basilar membrane to the range of audible frequencies in ground dwelling mammals. Journal of the Acoustical Society of America 77, 1091-1101. doi: $10.1121 / 1.392227$

Woodward, A. S., 1900. On some remains of Grypotherium (Neomylodori) listai and associated Mammals from a Cavern near Consuelo Cove, Last Hope Inlet, Patagonia. Proceedings of the Zoological Society of London 69(1), 64-78. doi: 10.1111/j.1096-3642.1890.tb01704.x 